\title{
Who Trusts Insurance? Empirical Evidence from Seven Industrialised Countries ${ }^{\dagger}$
}

\author{
Christophe COURBAGE ${ }^{\mathrm{a}, \mathrm{b}^{*}}$ \\ Christina NICOLAS ${ }^{\mathrm{a}, \mathrm{c}}$ \\ ${ }^{a}$ Geneva School of Business Administration \\ University of Applied Sciences Western Switzerland (HES-SO) \\ ${ }^{b}$ The Geneva Association, Zurich, Switzerland \\ ${ }^{c}$ Université de Limoges, LAPE, Limoges, France
}

This draft 28 May 2019

\begin{abstract}
While the importance of trust in insurance is widely recognised, surprisingly, existing literature on the determinants of trust in insurance remains scarce. This paper investigates the determinants of trust in insurance in seven industrialised countries in Europe, North America and Asia using data from a recent insurance industry survey. We find that trust in insurance is higher among females, younger individuals, and less educated people. On the contrary, people who are more insurance literate have higher trust in insurance. Our findings also show that experiences with insurance are one of the most important determinants of trust in insurance, with the negative effect of a bad experience being more pronounced than the positive effect of a good experience. Finally, access to information related to insurance through the internet deters trust in insurance, while access to information through newspapers and magazines promotes it.
\end{abstract}

JEL Classification: D12, G22

Keywords: Insurance; Trust; Insurance literacy

$\uparrow$ We are very grateful to The Geneva Association for permission to access survey data.

* Corresponding author. Email: christophe.courbage@ hesge.ch 


\section{Introduction}

The insurance industry, more than any other financial industry, is based on trust. Insurers, in exchange of a premium, promise to pay an indemnity if an adverse event occurs in the future. Without trust in insurance, it is very unlikely that individuals would decide to buy insurance (Guiso, 2008). Understanding trust in insurance is therefore crucial as, not only it shows how insurers are perceived, but most importantly it helps explain why people are willing or not to buy insurance.

Trust has for long been considered as an important driver of any economic activity (Arrow, 1972) and a rich literature exists on the role of trust in financial and economic development (see e.g. Bjornskov 2012; Gennaioli et al., 2015). Other studies focus on the determinants of trust in financial institutions but this literature is less developed and mainly includes studies on trust in banks (see e.g. Sapienza and Zingales, 2012; Fungácová et al., 2019).

While the importance of trust in insurance is well recognised (Schanz, 2009; Guiso, 2012), surprisingly, very little has been documented on the determinants of trust in insurance. To the best of our knowledge, only two papers exist in the literature on trust in insurance. The first paper is the one by Guiso (2012), who explores the importance of trust in determining the demand for insurance. The author also briefly studies a limited set of determinants of trust in insurance among small Italian entrepreneurs and finds a significant role played by the degree of satisfaction with insurance policies. The paper also finds significantly lower trust in insurance among male respondents. The second paper by Van Dalen and Henkens (2018) investigates trust in pension institutions, including insurance companies in Netherlands. This paper finds that the perceived integrity, competence, stability and benevolence of insurance companies matter in assessing their trustworthiness. The paper also shows that more educated participants have a significantly higher propensity to trust insurers.

Despite the contribution of the above literature, we still know little about what drives trust in insurance around the world. Our work aims to fill this gap in the literature by empirically studying the main determinants of trust in insurance in a cross-country setting using novel data. More specifically, we aim to contribute to the literature in the following ways. First, we do not focus on specific business lines such as pension providers, but on the insurance industry as a whole. Second, we take single country studies a step further by using a sample of seven highincome countries in Europe, North America and Asia. This provides additional geographic and cultural heterogeneity in our empirical analysis. Third, we use a large set of variables which might influence trust in insurance; from socioeconomic characteristics, behavioural traits, insurance literacy, means of access to information, to past good and bad experiences with insurers. Fourth, we address different dimensions of trust in insurance, being trust in the industry in general, and trust in specific operations of the insurance industry. Fifth, we make use of a novel comprehensive survey which is conducted with questions specific to the insurance industry, which makes our study unique and based on original data.

More specifically, our empirical analysis in this paper is based on an exclusive recent survey carried out by The Geneva Association which includes a comprehensive questionnaire on the insurance industry conducted in the following high-income countries: the United States, United Kingdom, Germany, France, Italy, Switzerland, and Japan. The survey contains questions related to various types of trust in insurance as well as individual characteristics and preferences. To estimate our data, we run an ordered logit model using individual trust in insurance companies as a dependent variable on a large set of explanatory variables. We find that trust in insurance is higher among females, younger individuals, and less educated people. On the contrary, people who are more insurance literate have higher trust in insurance. We also find that experiences with insurance are one of the most important determinants of trust in insurance, with the negative effect of a bad experience being more pronounced than the positive 
effect of a good experience. Moreover, access to information related to insurance through the internet deters trust in insurance, while access to information through newspapers and magazines promotes it. Finally, we find that French and German have relatively lower trust in insurance.

Given the importance of trust in the willingness to buy insurance, the implications of our findings are of high relevance for policy-makers and the insurance industry. In particular, by making individuals more knowledgeable of insurance and limiting bad experiences, trust in insurance is boosted; consequently, the demand for insurance products is expected to rise.

This article is organised as follow. Section 2 briefly reviews the related determinants of trust in general as well as trust in different financial institutions. Section 3 is devoted to the presentation of the database and the variables used. Section 4 presents the econometric methodology and discusses the main results. Section 5 provides further investigations and robustness checks. Finally, section 6 offers some concluding remarks and policy recommendations.

\section{Literature Review}

Over the last two decades, trust has evolved to become a prominent concern in various fields. Perhaps the most comprehensive definition of trust is the one which appears in Gambetta (1988): "trust is a particular level of the subjective probability with which an agent assesses that another agent or group of agents will perform a particular action, both before he can monitor such action and in a context in which it affects his own action". It follows that trust is dependent on both the propensity of trust of the individual who has to trust and the perceived trustworthiness of the subject trusted (Mayer et al., 1995).

According to Arrow (1972), an element of trust is certainly found in every commercial transaction executed. Economic and social well-being are found to prosper in societies with high levels of trust (Arrow 1972, Fukumaya 1975). Thus, trust is widely considered as an essential lubricant to any economic activity. In that respect, a wide strand of literature exists on the role of trust in the success of different economic phenomena. The focus of this literature has been mainly on general trust and its contribution to financial development, economic growth and prosperity (Knack and Keefer, 1997; Guiso 2004, 2008, 2010; Bjornskov 2012; Gennaioli et al., 2015).

An important strand of literature focuses on analyzing the role of socio demographic factors in determining general trust. Glaeser et al. (2000) show that trust is higher among high social status individuals. Likewise, Taylor-Gooby (2005) finds that trust in state and non-state pensions in the U.K. is higher among more privileged groups. Ennew and Sekhon (2007) provide evidence that trust is lower among older individuals. Helliwell and Putnam (2007) show that education boosts trust levels. This is confirmed by Charron and Rothstein (2016) who also find that that the positive effect of education on trust is conditional to a well-developed institutional and legal environment ${ }^{1}$.

Some other studies analyse the determinants of trust in the financial sector, mainly focusing on single country studies and banks. Lachance and Tang (2012) show that age and risk aversion decrease trust levels in financial professionals in the U.S. They also show that financial literacy boosts trust in financial professionals, but this positive effect turns negative for high levels of financial literacy. Knell and Stix (2015) and Jansen et al. (2015) explore trust in banks, respectively in Austria and in The Netherlands. However, these studies provide contradictory results whereby the former finds significant effect of socio demographic characteristics of individuals on trust levels while the latter does not find any significant effect. Jansen et al.

\footnotetext{
${ }^{1}$ For further studies on education and trust, see Huang et al. (2011), Putnam (2000), Helliwell and Putnam (2007,) and Borgonovi (2012)
} 
(2015) attribute the shift of trust in banks to events such as negative news and non-transparent product information. Shim et al. (2013) studying young adults' trust in U.S. banks find that selfreported well-being and financial status are significant drivers of trust. More recently, Fungacova et al. (2019) perform a more comprehensive cross-country study on the determinants of trust in banks. They document that trust in banks is higher among younger people, women, religious individuals and individuals with lower levels of income.

Surprisingly, despite the importance of the insurance industry in the financial sector, the literature on trust in insurance remains scarce. The only papers we are aware of are Guiso (2012) and Dalen and Henken (2018). Guiso (2012) mainly discusses and provides evidence using Italian data on a significant effect of trust on insurance demand. The study also briefly discusses a limited number of determinants of trust in insurance among a selection of Italian entrepreneurs and confirms a significant role played by the degree of satisfaction with insurance policies. The paper also finds significantly lower trust in insurance among male respondents. Dalen and Henken (2018) explore trust in pension institutions in general and in particular in insurance companies offering pension products in the Netherlands. They show that integrity, stability as well as benevolence of insurance companies are significant determinants of their trustworthiness. The paper also provides evidence that trust in insurance is higher among more educated and younger individuals.

\section{Data and variables}

\subsection{Sample and data sources}

In this paper, we make use of a recent Geneva Association survey conducted by Edelman Intelligence in March 2018. The survey includes a comprehensive questionnaire on the insurance industry conducted in seven high-income countries: The United States, United Kingdom, Germany, France, Italy, Switzerland, and Japan. The survey is based on an average of 1000 respondents per country with a good age, region, gender as well as income spread. Our total sample consists of 7434 cross-country individual observations. Table A1 of Appendix A represents detailed explanation of all variables employed in this study.

\subsection{Dependent variable: trust in insurance}

The main dependent variable in our investigation is the individual self-reported trust in insurance companies (TRUST_INS_COMP). This variable codes the answers to the following question:

When thinking about insurance companies, how much do you agree or disagree with the following statements: insurance companies are trustworthy?

Answers are reversed and coded as follows: 1 for strongly disagree, 2 for somewhat disagree, 3 for neither agree nor disagree, 4 for somewhat agree, and 5 strongly agree. The variable is thus an ordinal variable scaled from one to five with higher values indicating higher trust in insurance. 


\subsection{Independent variables}

\subsubsection{Socioeconomic factors}

Concerning explanatory variables, we start by including a set of socioeconomic indicators. We aim to determine whether socio-demographic/economic factors are significant determinants of trust in insurance. For this purpose, we include the vector socio_eco_factors that contains a various set of indicators that we detailed here below.

First, we proxy for gender, the dummy variable gender takes the value of 1 if the subject is a male and zero otherwise. Next, we use the variable age, which is the age of the subject in years. Age in our sample ranges from 18 to 93. We control for education following Helliwell and Putnam (2007). We wish to unravel whether education boosts or hinders trust in insurance especially that results in the literature on general education and trust have been controversial. The variable education is measured by the last grade in school attended. It takes the following values: 1 for graduate school or less, 2 for some secondary school or equivalent, 3 for finishing secondary school or equivalent, 4 for vocational/technical school, 5 for some university/higher education, 6 university/honors degree, 7 post-graduate degree. Income is the household annual income in 2017. It takes the value of 1 for low income, 2 for middle income, and 3 for high income ${ }^{2}$.

We also use a dummy variable (chiefincome_earner) to control for whether the subject interviewed is the chief income earner in the household or not. Being the chief income earner in a household could be linked to being the one responsible for contracting insurance which might make the subject more trusting in insurance. To study whether trust in insurance is different according to the living area characteristics, we use the variable area_living which takes the values of 1 if the subject lives in the heart of a large city, 2 for an urban area, 3 for a suburban area, 4 for a semi-rural area, and 5 for a rural area. Individuals who live in rural areas might be less informed and thus less trusting than those who live closer to large city center. We also include a dummy variable accounting for the presence (1) or not (0) of children in the household. Finally, to account for unemployment as in Charron and Rothstein (2016), we add a dummy variable "unemployed" which takes the value of 1 if the subject is unemployed and zero otherwise.

\subsubsection{Insurance literacy}

We are interested in studying the effect of specific knowledge of the insurance industry on trust in insurance. We dub knowledge of the insurance industry, insurance literacy. This variable is recorded as the answer to the following question:

\section{How would you qualify your level of understanding/knowledge of the insurance industry?}

The answers are scaled from 1 to 5 as follows: 1 for very poor, 2 for poor, 3 for fair, 4 for good, and 5 for very good. This variable is of particular interest in our study as we are interested in finding whether individuals' trust in insurance is higher among those who are more familiar with the industry specifically. We expect a positive effect of this variable on trust as we suspect that individuals with higher financial literacy in the insurance industry may be able to grasp much easier how insurance functions, be less sceptical, and thus might have higher levels of trust in insurance.

\footnotetext{
${ }^{2}$ Income is split into the three categories (low, middle, and high) depending on the perceived salary spreads in each country.
} 


\subsubsection{Experiences with insurance}

Next, we hypothesize that experiences from the past could have an effect on current trust levels. Alesina and Ferrara (2002) show that traumatic history is one of the most significant determinants of trust. In his study on Italian insurance companies, Guiso (2012) finds that the degrees of satisfaction with insurance policies are one of the most important determinants of trust in insurance. To test the importance of previous experiences with insurance on trust, we add to our model the vector past experiences which includes two dummy variables: the presence of good experience and the presence of a bad experience. More specifically the variable good_experience records the answer to the following question:

Have you ever had, or know someone who has had, a good experience with insurance?

Likewise, the variable bad experience records the answer to the following question:

Have you ever had, or know someone who has had, a bad experience with insurance?

These dummy variables take the value of 1 if the answer is "yes" and zero if the answer is "no". Obviously, we expect a positive sign on the good experience variable and a negative sign on the bad experience. We also wish to assess which of the two impacts is a more important determinant of trust in insurance.

\subsubsection{Traits of character}

We include a set of personal characteristics (traits ${ }_{1}$ ) which we suspect might influence trust levels.

First, we include a dummy variable on optimism which takes the value of 1 if the individual considers himself/herself optimistic and zero otherwise. Optimism is expected to have a positive influence on trust since more optimistic individuals tend to be happier and happiness has been shown to promote trust (Mislin et al., 2015).

Second, we wish to study the effect of the importance of the future with respect to the present on trust in insurance. For this purpose, we include the variable future_oriented which reports answers to the following: I tend to focus on the present more than the future. Answers available are coded as follows: 1 strongly agree, 2 somewhat agree, 3 neither agree nor disagree, 4 somewhat disagree, and 5 strongly disagree. Hence, higher levels of this variable indicates that the individual is more future oriented.

Third, we add to our model a dummy variable on altruism which represents the answer to the following: I feel responsible for taking care of my family. Likewise, answers available are coded as follows: 1 strongly agree, 2 somewhat agree, 3 neither agree nor disagree, 4 somewhat disagree, and 5 strongly disagree. Hence, higher values indicate lower levels of altruism.

\subsubsection{Information source}

Finally, access to information regarding insurance can influence the level of trust in insurance. Following Fungacova et al. (2019), we include two variables regarding the source of access to information on insurance: info_newspaper represents the answer to the following question:

\section{Do you search for information regarding insurance products using newspapers?}

As for info_internet, it codes answers to the following question: 
Do you search for information regarding insurance products using an internet search engine?

Variables are set equal to one if the answer of the respondent is yes and zero otherwise.

\subsection{Descriptive statistics}

Table 1 presents the descriptive statistics of the full sample. Table 2 displays variable means by country. TRUST_INS_COMP shows a sample average of 2.72 on a scale of 1 to 5. Highest levels of trust in insurance companies is found in the U.K. Germany shows the average highest insurance literacy among the sample countries. Having a bad experience with insurance is at its record low in Japan (0.26) while being the highest in Switzerland (0.65).

Table 3 displays the correlation matrix. No major correlation exists between independent variables, which implies that our regression analysis does not suffer from any multicollinearity issues. We also perform the variance inflation factor (VIF) for further confirmation. We obtain a VIF much lower than 10 which again alleviates multicollinearity issues.

[INSERT table 1 here]

[INSERT table 2 here]

[INSERT table 3 here]

\section{Econometric analysis}

\subsection{Empirical model and methodology}

We start by employing the following model to estimate our data:

$$
\text { [1] TRUST_INS_COMP }=\gamma_{0}+\sum_{f=1}^{F} \gamma_{f} \text { socio_eco_factors } f_{f}+\beta \text { insurance_litteracy }_{+} \varepsilon
$$

We then incorporate additional covariates as follows:

[2] TRUST_INS_COMP $=\gamma_{0}+\sum_{f=1}^{F} \gamma_{f}$ socio_eco_factors $S_{f}+\beta$ insurance_litteracy + $\sum_{k=1}^{K} \mu_{k}$ past_experience ${ }_{k}+\sum_{l=1}^{L} \omega_{l}$ traits $_{l}+\sum_{m=1}^{M} \phi_{m}$ info_source $_{m}+\varepsilon$

Alternatively, we control for country specific effects by adding to our model country dummies:

$$
\begin{aligned}
& \text { [3] TRUST_INS_COMP }=\gamma_{0}+\sum_{f=1}^{F} \gamma_{f} \text { socio_eco_factor }_{f}+\beta \text { insurance_litteracy }+ \\
& \qquad \sum_{n=1}^{7} \eta_{n} C D_{n}+\varepsilon \\
& \text { [4] TRUST_INS_COMP }=\gamma_{0}+\sum_{f=1}^{F} \gamma_{f} \text { socio_eco_factors }_{f}+\beta \text { insurance_litteracy }++ \\
& \sum_{k=1}^{K} \mu_{k} \text { past_experience } e_{k}+\sum_{l=1}^{L} \omega_{l} \text { traits }_{l}+\sum_{m=1}^{M} \phi_{m} \text { info_source }_{m}+ \\
& \sum_{n=1}^{7} \eta_{n} C D_{n}+\varepsilon
\end{aligned}
$$

We use an ordered logit model to estimate the above models since our dependent variable TRUST_INS_COMP is an ordinal variable which takes discrete values. We use four different 
specification in our main analysis to assess the importance of different determinants. First, we estimate our model [1] using only socio-economic characteristics and measures of insurance literacy. Next, we estimate the full model by adding the remaining covariates as in Model [2]. Finally, we run the first two specifications with country dummies in specifications [3] and [4]. In addition, we complement our analysis by analysing marginal effects in our further investigations section.

\subsection{Main regression results}

In this section, we present the main results on the determinants of trust in insurance (Table 4).

Starting with socio-economic factors, we first find a strong gender gradient whereby women trust insurance much more than men. This is in line with previous literature on trust in banks and insurance (see e.g. Guiso, 2012; Knell and Stix, 2015; Fungácová et al., 2019). Hence, women might be more likely than men to purchase insurance if they had to decide on such a purchase.

Trust in insurance is found to decrease with age. As people age, they might become more sceptical of insurance and have less trust in it. Hence, all other things being equalled, young people might be more willing to buy insurance than older people. This result is also in accordance with previous works on trust in banks (Ennew and Sekhon, 2007; Fungácová et al., 2019).

As for education, a higher level of education tends to deteriorate trust in insurance. This contrasts with previous results by Van Dalen and Henkens (2018) showing that more educated people trust more insurance companies offering pension products in The Netherlands. Yet, it is in accordance with the results of Fungácová et al. (2019) regarding trust in banks. A possible explanation is that better educated people are more likely to become sceptical of insurance.

According to our results, income, unemployment, and being the chief income earner in a household are not significant determinants of trust. On the contrary, the living area as well as house ownership strongly influence the level of trust. Those living in large cites tend to have more trust in insurance than those living in rural areas. Likewise, individuals who are house owners tend to have more trust in insurance.

Insurance literacy, i.e. the level of understanding and knowledge of the insurance industry, is shown to strongly positively influence the level of trust in insurance. This result may be related to the degree of complexity of the insurance industry. Those with low financial literacy in the insurance industry may find highly complex the mechanisms of insurance and do not really grasp how insurance functions, lowering their trust in insurance. On the contrary, those understanding how insurance works and aware of its potential benefits are less sceptical about insurance and trust it more.

Past experience with insurance, being good or bad, also strongly influences the level of trust in insurance. Those who had a good experience with insurance tend to have more trust in insurance. Individuals with bad experience with insurance tend to have less trust in insurance than individuals with no history of bad experience. In the following section, we further investigate the elements defining a bad experience in insurance. These results are in line with Guiso (2012) who shows that the level of satisfaction with insurance policies, i.e. how the insurance adhered to the contractual obligations and respected the client's interests, raises substantially the level of trust. Also, these results are in accordance with Alesina and Ferrara (2002) who show that traumatic history is one of the most significant determinants of trust.

Regarding individual character traits, optimistic individuals, altruistic individuals and future oriented individuals, tend to have higher trust in insurance. Indeed, optimistic individuals tend to overweigh good outcomes and underweight bad ones, which makes them less sceptical about insurance. Altruistic individuals, who are more caring about other, might be more sensitive to 
the importance of helping people in need, and thus might be more aware of the benefits of insurance, the fact which might make them more trusting in insurance.

Concerning information sources, we find that the type of access to information related to insurance is also a significant determinant of insurance trust. Access to information related to insurance through newspapers and magazine enhances trust in insurance. Access to the internet, in contrast, has the opposite effect. Hence, our results show that the means of access to information can be beneficial or detrimental to trust in insurance, depending on the source of this information. This confirm earlier results on the influence of the type of access to information on trust in banks (Fungácová et al., 2019). An explanation to this is that the internet can be seen as a platform for spreading negative news, rumours or even fake news, while newspapers and magazines might be offering more objective and solid information and thus do increase the confidence of their audience in insurance products.

Finally, we display results for country dummies. France is the country dropped for collinearity among the seven country dummies in the regression. Results show that individuals from countries in France and Germany have lower trust in insurance compared to remaining countries. On the contrary, individuals from Switzerland and the U.K. show the highest trust levels in insurance.

[INSERT table 4 here]

\subsection{Marginal effects}

To further analyse the magnitude of the effect of our explanatory variables in determining trust in insurance, we conduct marginal effects analysis. We present in Table 5 marginal effects of the five different outcomes of trust using model $[4]^{3}$. Hence, we are interested in complementing our analysis in the previous section which outlined the sense of the significance of the variables by quantifying the impact of these variable in order to point their relative importance in determining the drivers of trust in insurance as well as the elements that highly deter it.

For simplicity in the interpretation, we focus on commenting on the higher trust outcomes, i.e., outcomes 4 and 5 knowing that the opposite interpretation also applies. As in the main regression, we find no significance of income, children, and unemployment on trust. All other variables show significant marginal effects on different trust outcomes. In terms of magnitude, results in Table 5 show that a bad experience shows the highest negative marginal effect on outcome 5: having had a bad experience with insurance decreases the probability of a response in the highest category of trust by 2.6 percentage points. As for drivers of a high trust level, we find that having a good experience with insurance as well as being insurance literate (increase by a one standard deviation) increases the probability of a response in category 5 by 2.3 percentage points and 1.1 percentage points respectively. This effect is actually much more pronounced on a response in category 4 whereby having a good experience with insurance as well as being insurance literate (by a one standard deviation) increases the probability of a response in this category by 12.4 percentage points and 5.9 percentage points respectively. Moreover, a bad experience highly deters trust in insurance among respondents in category 4 , with an impressive 13.6 percentage points decrease in a response in this category following a bad experience with insurance. As such, results show that the intensity of the effect of experience with insurance is higher if the experience is bad than if it is good. Hence, bad experience with insurance is more detrimental to trust than good experience is beneficial to trust. Insurers should then allocate more resources to avoid bad experience than to offer good experience to their customers.

\footnotetext{
${ }^{3}$ For simplicity reasons and to gain space. Results using the three other models are available upon request.
} 
Concerning socio-economic factors, we find a negative impact of 2.5 percentage points of gender and a positive impact of 3 percentage points of being a house owner on the probability of a response in category 4 . In other words, if the respondent is a male, there is 1.1 percentage points less chance to answer neither agree nor disagree, 2.5 percentage points less chance to answer somewhat agree, and 0.4 percentage points less chance to answer strongly agree with the trustworthiness of insurance. Being old and educated also significantly decreases the probability of a response in higher trust categories but with a lower magnitude compared to gender.

Concerning traits of character, being optimistic increases the chance of a response (4) by 1.8 percentage points while being future oriented decreases it by 1.1 percentage points. Finally, concerning information sources, results show that using the newspaper increases the probability of a response in category 4 by 2 percentage points ( 0.3 for category 5$)$ while using the internet decreases the probability of a response in category 4 by 2.3 percentage points $(0.45$ for category $5)$.

\section{[INSERT table 5 here]}

\section{Further investigations and robustness checks}

In this section, we look further at the elements of bad experience in insurance by replacing the bad experience dummy in the main regression with dummies on specific bad experiences. We also run regressions by countries, consider an alternative measure of trust in insurance, and use binary variables for insurance literacy and education. Finally, we perform several robustness checks.

\subsection{Elements of bad experience in insurance}

The survey provides various elements that define the kind of past bad experiences that individuals had with insurance, ranging from claim payment to usefulness and complexity of the products.

Results by elements of bad experiences are presented in Table 6 . The first elements concern claim management, specifically delayed claim payments, difficulty to make a claim, and denied claim payment. These three elements have all a negative impact on trust in insurance. This is expected as trust in insurance is strongly linked to the promise and ability of insurers to pay an indemnity if an adverse event occurs. Hence, having a bad experience with claim management questions the main function of insurance and casts doubt on the ability of insurers to fulfil their promise. It is worth noting that a denied claim is the factor that decreases trust the most as we observe the highest coefficient on the Denied_Claim variable.

The other element of past bad experience in insurance relates to having experienced a complicated and lengthy process to purchase insurance. Having had difficulty in buying insurance decreases the level of trust in insurance. This could occur as difficulty in buying insurance could be seen as signal that all the other insurance function processes could experience the same difficulty and especially reimbursement of losses. Hence individuals experiencing difficulty in buying insurance would trust less insurers in general and in particular their ability to fulfil their promise, decreasing then trust in insurance. The effect of this variable is however lower compared to the above elements which relate to claim management

From the above analysis, one could infer that all aspects related to bad experiences with insurance claims are the most important determinants of trust in insurance, with claim denial having the highest negative influence on trust. 


\subsection{Results by country}

To go further in our analysis, we run model [4] separately for each of the seven countries of our sample. Although we include country dummies in our main regression, we also perform country-by-country regressions since we are specifically interested in studying whether experiences with insurance and insurance literacy are also significant when we consider one country at a time. Results are displayed in Table 7. Results show that past experience with insurance, being good or bad, and financial literacy influence trust in insurance in all the countries under study. This further confirms our findings that past experiences with insurance as well as financial literacy are by far the most important determinants of trust in insurance as they also persist in all country sub-samples.

\section{[INSERT table 7 here]}

\subsection{Alternative measure of trust in insurance}

We replace our main dependant variable, general trust in insurance companies, by the following variable: trust_ins_reimb, which is the trust in insurance reimbursement. This variable is also scaled from 1 to 5 coding answers (1 strongly disagree, 2 somewhat disagree, 3 neither agree nor disagree, 4 somewhat agree, 5 strongly agree) to the following statement:

\section{Insurance products payout/reimburse the insured person when they are supposed to.}

We wish to study whether our main results for general trust in insurance also hold for specific trust in reimbursement. For this purpose, we run the same regressions as in our main regression analysis with trust_ins_reimb as dependent variable in the four specifications. Results are displayed in Table 8 . We observe that our results persist and are mostly similar to the main regression results.

[INSERT table 8 here]

\subsection{Insurance literacy and education}

In their paper, Lachance and Tang (2012) show that financial literacy increases trust in financial advisory. However, they document a non-linear effect of financial literacy on trust by showing that very high levels of the former reduces trust levels. Consequently, we are interested in studying the effect of insurance literacy on trust in insurance for different levels of literacy. Likewise, we wish to investigate further whether different levels of education might influence trust differently. For this purpose, we replace the ordinal variables in the main regression accounting for insurance literacy and education by dummy variables for every existing outcome 
for each variable ${ }^{4}$. Results are displayed in Table 9. Results show that all levels of education are negatively significant. Individuals having moderate and high levels of education tend to trust insurance less than poorly educated ones. Findings for insurance literacy show that the positive effect of insurance literacy on trust rises substantially when passing to a higher level of literacy. An exponential effect on trust is even observed for the higher categories of insurance literacy (e.g., a coefficient of 2.48 for very good level of insurance literacy is recorded versus 0.47 for poor literacy, taking very poor insurance literacy as a benchmark). Hence, our results do not provide evidence of a non-linear effect of insurance literacy on trust. Once again, our findings confirm the importance of promoting insurance literacy and achieving high levels of knowledge of insurance products among individuals by showing that even highest levels of insurance literacy do promote trust in insurance and to a higher extent compared to moderate levels of literacy.

\section{[INSERT table 9 here]}

\subsection{Other robustness checks}

We perform several robustness checks to confirm the validity of our findings. First, we estimate our model with linear estimation techniques using Ordinary Least Square and obtain similar results (see Table B1, Appendix B). Second, we transform our dependent variable TRUST_INS_COMP which is an ordinal variable into a dummy variable (dum_TRUST_INS_COMP) equal to 0 for no trust in insurance and 1 for having trust in insurance. We do so by setting answers to the main question on trust in insurance companies as follows: answers 1 (strongly disagree) and 2 (somewhat disagree) are set to zero. Likewise, we set outcomes 4 (somewhat agree) and 5 (strongly agree) to $1^{5}$. We re-run our main regressions using the dummy variable (dum_TRUST_INS_COMP) as dependant variable and use a logit model to estimate all models 1 to 4 . Despite losing about one third of the observations with this transformation, results obtained are very similar to the results obtained with the main ordinal variable (see Table B2, Appendix B) Third, we run our main regression removing one country at a time to make sure our results are not driven by a specific country. Results are presented in Table B3 of Appendix B. Removing a country from the sample does not alter our findings which implies that our results are not driven by a specific country.

\section{Conclusion}

This paper investigates the determinants of trust in insurance in seven industrialised countries in Europe, North America and Asia using data from a novel insurance industry survey.

Our results show that socioeconomics factors, individual character traits, insurance literacy, the type of access to information related to insurance as well as past experience with insurance drive the level of trust in insurance. Women trust insurance much more than men. Trust in insurance tends to decrease with age and education, but increases with insurance literacy. The positive effect of trust is even more pronounced for very high levels of insurance literacy. Optimistic individuals, altruistic individuals and individuals with high preferences for the present tend to have higher trust in insurance. Access to information related to insurance

\footnotetext{
${ }^{4}$ The lowest outcome of insurance literacy (very poor knowledge of the insurance industry) is dropped for collinearity and serves as benchmark. Likewise, the lowest level of education (Primary school or less) is dropped and serves as benchmark.

${ }^{5}$ We disregards outcomes 3 , the neutral response (neither agree nor disagree).
} 
through newspapers and magazine enhances trust in insurance, while access to information through the internet has the opposite effect. Moreover, we also show that individuals from France and Germany have the lowest level of trust among the sample countries. While, individuals from the U.K. and Switzerland have relatively higher trust in insurance.

Past experiences with insurance, both good and bad strongly influence the level of trust in insurance. Interestingly, bad experience with insurance seems more detrimental to trust than good experience is beneficial to trust. When we further analyse the elements of bad experiences in insurance, bad experiences with claim management have the strongest negative impact on trust in insurance. Having experienced a complicated and lengthy process to purchase insurance is another element of bad experience strongly and negatively affecting trust in insurance.

Our findings offer some interesting new insights on the determinants of trust and the willingness to buy insurance since trust in insurance is considered a strong driver of insurance purchase (Guiso, 2012). Understanding what shapes trust in insurance is essential to developing policies to enhance insurance coverage. It follows that our findings could be of specific interest to insurance professionals and policy makers who might make use of main trust determinants in order to improve trust in insurance. Specifically, our analysis shows that bad experience with insurance is more detrimental to trust than good experience is beneficial to trust. It follows that insurers might benefit if they allocate more resources to avoid bad experiences than to offer good experiences to their customers. In that respect, they might want to avoid delaying claim payments or making claim reimbursement and the process to buy insurance as simple and straightforward as possible. In addition, given that trust increases significantly with insurance literacy, insurers should be more active in communicating and diffusing knowledge on the mechanisms and specificities of insurance to a larger audience. Targeting women, younger people, and less educated individuals might also boost insurance demand since our findings provide solid evidence of higher trust levels in insurance among women, young and less educated respondents.

Our work constitutes a first step towards a better understanding of the determinants of trust in insurance and may provide a prelude for further research in the field. 


\section{References}

Alesina, A., Ferrara, E., (2002). "Who trusts others?”. Journal of Public Economics 85 (2), 207-34.

Arrondel, L., Debbich, M., Savignac, F., (2013). "Financial literacy and financial planning in France". Numeracy 6: Issue 2, Article 8.

Arrow, K. J. (1972). "Gift and exchanges". Philosophy and Public Affairs 1, 4, 343-62.

Bjornskov, C., (2008). "Social trust and fractionalization: A possible reinterpretation". European Sociological Review 24, 271-283.

Charron, N., Rothstein, B., (2016). "Does education lead to higher generalized trust? The importance of quality of government". International Journal of Education Development 50, 59-73.

Ennew, C. and Sekhon, H., (2007). "Measuring trust in financial services: The trust index". Consumer Policy Review 17(2), 62-68.

Fukuyama, F., (1995). "Trust: The social virtues and the creation of prosperity". New York: Free Press.

Fungáčová, Z., Hasan, I.,Weill, L., (2019). “Trust in banks”. Journal of Economic Behavior \& Organization, 157, 452-476.

Gambetta, D., (1998). "Can we trust trust?" in Trust: Making and Breaking Cooperative Relations, D. Gambetta (ed), Basil Blackwell, Cambridge: MA. chapter 13, 213-237.

Gennaioli, N., La Porta, R., Lopez-de-Silanes, F., Shleifer, A., (2013). "Human capital and regional development". Quarterly Journal of Economics, 128(1), 105-16.

Glaeser, E., Laibson, D., Scheinkman, J., Soutter, C., (2000). "Measuring trust". Quarterly Journal of Economics 115, 811-846.

Guiso, L., (2010). "A trust-driven financial crisis: Implications for the future of financial markets". European University Institute, Economics Working Papers.

Guiso, L., (2012). "Trust and Insurance Markets”. Economic Notes 41 (1-2), 1-26.

Guiso, L., Sapienza, P., Zingales, L., (2008). "Trusting the stock market”. Journal of Finance 63, 2557-2600.

Guiso, L., Sapienza, P., Zingales, L., (2004). "The role of social capital in financial development". American Economic Review, 94, 526-56.

Helliwell, J. F., Putnam, R. D., (2007). "Education and social capital". Eastern Economic Journal 33 (1), 1-19.

Jansen, D.-J., Mosch, R., Van der Cruijsen, C. (2015). "When does the general public lose trust in banks?". Journal of Financial Services Research 48(2), 127-141.

Knack, S., Keefer, P., (1997). "Does social capital have an economic payoff? A cross-country investigation". Quarterly Journal of Economics 112 (4), 1251-1288.

Knell, M., Stix, H., (2015). "Trust in banks. Evidence from normal times and from times of crises". Economica 82, 995-1020.

Lachance. M., Tang, N., (2012). "Financial advice and trust”. Financial Services Review 21 (3), 209-26.

Mislin, A., Williams, L.V., Shaughnessy, B.A., (2015). "Motivating trust: Can mood and incentives increase interpersonal trust?". Journal of Behavioral and Experimental Economics $58,11-19$

Mayer, R.C., Davis, J.H., Schoorman, F.D., (1995). “An integrative model of organizational trust". Academy of Management Review 20(3), 709-734. 
Sapienza, P., Zingales, L., (2012). “A trust crisis". International Review of Finance, 12 (2), 123-131.

Schanz, K.-U., (2009). "Maintaining stakeholder trust in difficult times: some fundamental reflections in light of the credit crisis". The Geneva Papers on Risk and Insurance-Issues and Practice 34(2), 260-270.

Shim, S., Serido, J., Tang, C., (2013). "After the global financial crash: Individual factors differentiating young adult consumers' trust in banks and financial institutions". Journal of Retailing and Consumer Services 20 (1), 26-33.

Taylor-Gooby, P. (2005). "Uncertainty, trust and pensions: The case of the current UK reforms". Social Policy \& Administration 39(3), 217-232.

Van Dalen, H., P., Henkens, K., (2018). "The making and breaking of trust in pension providers: An empirical study of pension participants". The Geneva Papers on Risk and Insurance Issues and Practice 43 (3), 473-91. 
Table 1. Descriptive Statistics

\begin{tabular}{lllccc}
\hline Variable & Obs & Mean & Std. Dev. & Min & Max \\
\hline TRUST_INS_COMP & 7,434 & 2.724 & 0.967 & 1 & 5 \\
gender & 7,412 & 0.523 & 0.500 & 0 & 1 \\
age & 7,434 & 51.143 & 16.469 & 18 & 93 \\
education & 7,406 & 4.439 & 1.442 & 1 & 7 \\
income & 7,434 & 2.003 & 0.777 & 1 & 3 \\
chiefincome_earner_dum & 7,434 & 0.690 & 0.463 & 0 & 1 \\
area_living & 7,434 & 2.791 & 1.192 & 1 & 5 \\
children & 7,434 & 2.165 & 1.213 & 1 & 6 \\
house_ownership & 7,434 & 0.556 & 0.497 & 0 & 1 \\
unemployment & 7,434 & 0.147 & 0.354 & 0 & 1 \\
optimism & 7,434 & 0.185 & 0.389 & 0 & 1 \\
future_orientation & 7,434 & 2.619 & 0.961 & 1 & 5 \\
altruism & 7,434 & 2.030 & 1.042 & 1 & 5 \\
good_experience & 7,434 & 0.513 & 0.500 & 0 & 1 \\
bad_experience & 7,434 & 0.533 & 0.499 & 0 & 1 \\
insurance literacy & 7,434 & 2.825 & 0.930 & 1 & 5 \\
info_newspaper & 7,434 & 0.074 & 0.262 & 0 & 1 \\
info_internet & 7,434 & 0.378 & 0.485 & 0 & 1
\end{tabular}


Table 2. Descriptive Statistics by Country

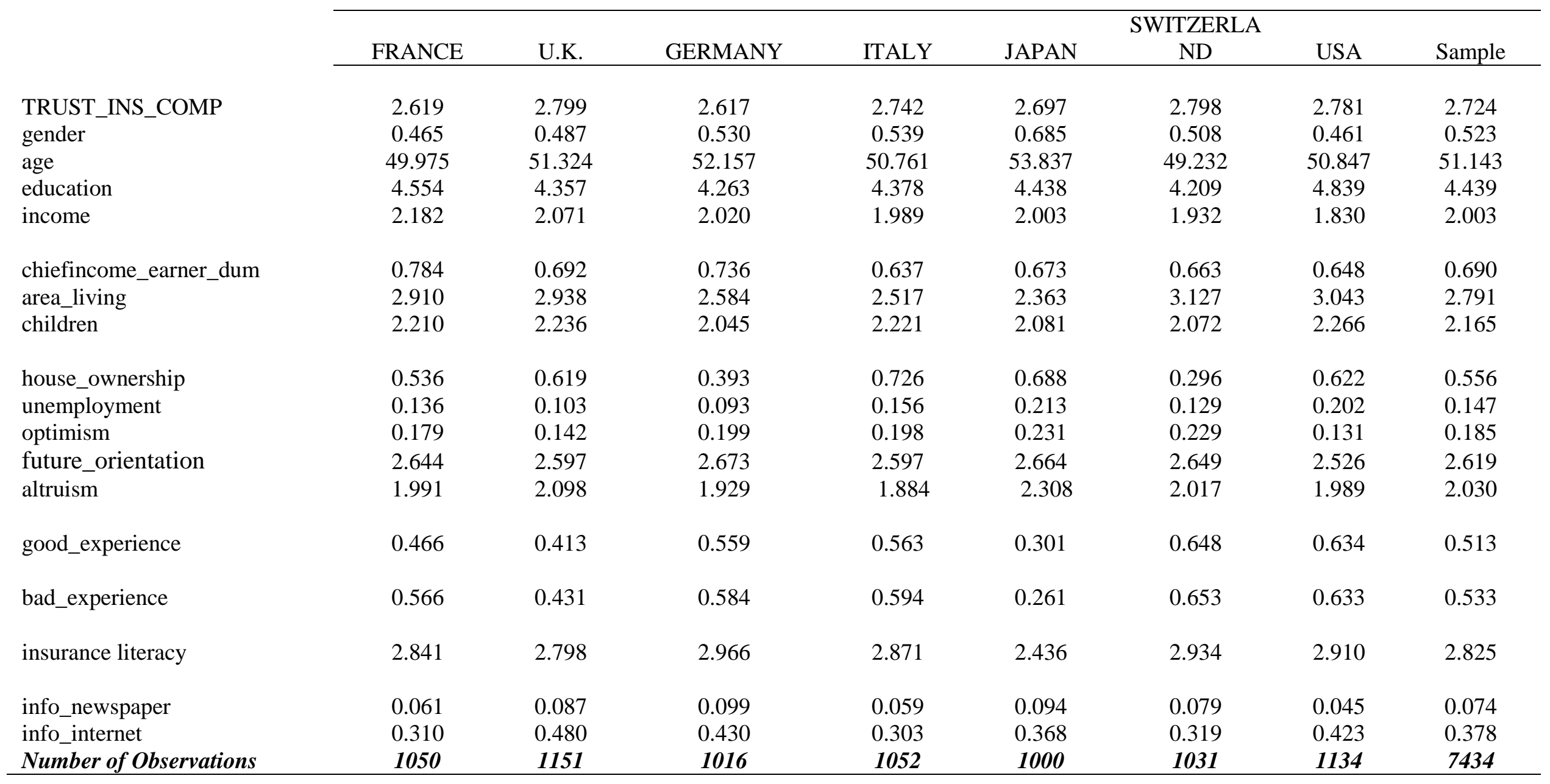

This Table displays country-level means of all variables. 
Table 3. Correlation Matrix

\begin{tabular}{|c|c|c|c|c|c|c|c|c|c|c|c|c|c|c|c|c|c|}
\hline & $\begin{array}{l}\text { TRUST_INS } \\
\text { _COMP }\end{array}$ & gender & age & education & income & $\begin{array}{l}\text { Chiefinco } \\
\text { me_earner }\end{array}$ & $\begin{array}{l}\text { Area } \\
\text { living }\end{array}$ & Children & $\begin{array}{l}\text { House } \\
\text { ownership }\end{array}$ & $\begin{array}{l}\text { unemploy } \\
\text { ment }\end{array}$ & optimism & \begin{tabular}{|l} 
Future \\
orientatio \\
$n$
\end{tabular} & altruim & $\begin{array}{l}\text { good_expe } \\
\text { rience }\end{array}$ & $\begin{array}{l}\text { bad_exper } \\
\text { ience }\end{array}$ & $\begin{array}{l}\text { info_news } \\
\text { paper }\end{array}$ & $\begin{array}{l}\text { info_inter } \\
\text { net }\end{array}$ \\
\hline $\begin{array}{l}\text { TRUST_INS } \\
\text { _COMP }\end{array}$ & 1 & & & & & & & & & & & & & & & & \\
\hline gender & -0.0331 & 1 & & & & & & & & & & & & & & & \\
\hline age & -0.0276 & 0.1727 & 1 & & & & & & & & & & & & & & \\
\hline education & 0.0084 & 0.0582 & -0.04 & 1 & & & & & & & & & & & & & \\
\hline income & 0.0467 & 0.074 & 0.013 & 0.269 & 1 & 1 & & & & & & & & & & & \\
\hline $\begin{array}{l}\text { chiefinco } \\
\text { me_earner }\end{array}$ & -0.0065 & 0.3613 & 0.213 & 0.078 & -0.0687 & 1 & 1 & & & & & & & & & & \\
\hline area_living & g $\quad-0.0333$ & -0.0162 & 0.088 & -0.094 & 0.0006 & -0.0651 & 1 & & & & & & & & & & \\
\hline children & 0.045 & -0.0229 & 0.27 & -0.008 & 0.1705 & 0.0344 & 0.03 & 1 & & & & & & & & & \\
\hline $\begin{array}{l}\text { house_ow } \\
\text { nership }\end{array}$ & 0.0752 & 0.0701 & 0.276 & 0.144 & 0.2691 & 0.0102 & 0.12 & 0.2053 & 1 & & & & & & & & \\
\hline $\begin{array}{l}\text { unemploy } \\
\text { ment }\end{array}$ & -0.0306 & -0.1809 & -0.19 & -0.102 & -0.2262 & -0.272 & -0.01 & -0.0824 & -0.133 & 1 & & & & & & & \\
\hline optimism & 0.0361 & 0.0228 & 0.031 & 0.016 & 0.0388 & 0.0187 & -0.03 & 0.0502 & -0.004 & -0.0409 & 1 & & & & & & \\
\hline $\begin{array}{l}\text { future_ori } \\
\text { entation }\end{array}$ & -0.0518 & -0.0017 & -0.01 & 0.052 & 0.0576 & -0.0076 & 0.01 & -0.0161 & 0.034 & -0.0104 & -0.0472 & 1 & & & & & \\
\hline altruism & -0.0709 & 0.0201 & -0.04 & -0.04 & -0.1633 & 0.0206 & -0.03 & -0.2819 & -0.103 & 0.0371 & 0.0161 & 0.0146 & 1 & & & & \\
\hline $\begin{array}{l}\text { good_expe } \\
\text { rience }\end{array}$ & 0.2422 & -0.0128 & 0.002 & 0.088 & 0.0849 & 0.0343 & 0.01 & 0.0758 & 0.054 & -0.0839 & 0.0055 & -0.0183 & -0.114 & 1 & & & \\
\hline $\begin{array}{l}\text { bad_exper } \\
\text { ience }\end{array}$ & -0.1935 & -0.0027 & -0.02 & 0.081 & 0.0339 & 0.0355 & 0.03 & 0.0414 & -0.002 & -0.0367 & -0.0128 & 0.0126 & -0.0968 & 0.23 & 1 & & \\
\hline $\begin{array}{l}\text { insurance } \\
\text { literacy }\end{array}$ & 0.2402 & 0.1038 & 0.072 & 0.116 & 0.1761 & 0.1313 & -0.01 & 0.1225 & 0.118 & -0.1661 & 0.0225 & -0.0119 & -0.1612 & 0.248 & 0.0956 & 1 & \\
\hline $\begin{array}{l}\text { info_news } \\
\text { paper }\end{array}$ & 0.0443 & 0.0643 & 0.021 & 0.052 & 0.0656 & 0.0393 & -0.03 & 0.0155 & 0.048 & -0.0209 & 0.0139 & 0.0008 & -0.0082 & 0.045 & 0.0045 & 1 & \\
\hline $\begin{array}{l}\text { info_inter } \\
\text { net }\end{array}$ & -0.0522 & 0.0195 & -0.08 & 0.037 & -0.0178 & -0.0098 & -0.03 & -0.0269 & -0.042 & 0.0461 & -0.0062 & -0.0125 & -0.0173 & $3.00 \mathrm{E}-04$ & 0.0415 & 0.0379 & 1 \\
\hline
\end{tabular}


Table 4. Determinants of Trust in Insurance - Main regression

\begin{tabular}{|c|c|c|c|c|}
\hline & $\begin{array}{c}(1) \\
\text { TRUST_INS_ } \\
\text { COMP }\end{array}$ & $\begin{array}{c}(2) \\
\text { TRUST_INS } \\
\text { COMP }\end{array}$ & $\begin{array}{c}\text { (3) } \\
\text { TRUST_INS } \\
\text { COMP }\end{array}$ & $\begin{array}{c}(4) \\
\text { TRUST_INS } \\
\text { COMP }\end{array}$ \\
\hline gender & $\begin{array}{c}-0.194 * * * \\
(-4.17)\end{array}$ & $\begin{array}{c}-0.191 * * * \\
(-4.05)\end{array}$ & $\begin{array}{c}-0.220 * * * \\
(-4.64)\end{array}$ & $\begin{array}{c}-0.197 * * * \\
(-4.12)\end{array}$ \\
\hline age & $\begin{array}{c}-0.00630 * * * \\
(-4.31)\end{array}$ & $\begin{array}{c}-0.00727 * * * \\
(-4.91)\end{array}$ & $\begin{array}{c}-0.00643 * * * \\
(-4.38)\end{array}$ & $\begin{array}{c}-0.00719 * * * \\
(-4.83)\end{array}$ \\
\hline education & $\begin{array}{c}-0.0361 * * \\
(-2.31)\end{array}$ & $\begin{array}{c}-0.0262^{*} \\
(-1.65)\end{array}$ & $\begin{array}{c}-0.0398^{* *} \\
(-2.51)\end{array}$ & $\begin{array}{c}-0.0306^{*} \\
(-1.90)\end{array}$ \\
\hline income & $\begin{array}{l}-0.0167 \\
(-0.54)\end{array}$ & $\begin{array}{c}-0.0371 \\
(-1.18)\end{array}$ & $\begin{array}{c}0.00492 \\
(0.16)\end{array}$ & $\begin{array}{c}-0.0223 \\
(-0.70)\end{array}$ \\
\hline $\begin{array}{l}\text { chiefincome_earner_ } \\
\text { dum }\end{array}$ & -0.0528 & -0.0342 & -0.0122 & -0.00788 \\
\hline & $(-1.01)$ & $(-0.65)$ & $(-0.23)$ & $(-0.15)$ \\
\hline area_living & $\begin{array}{c}-0.0575^{* * *} \\
(-3.16)\end{array}$ & $\begin{array}{c}-0.0496 * * * \\
(-2.69)\end{array}$ & $\begin{array}{c}-0.0633 * * * \\
(-3.35)\end{array}$ & $\begin{array}{c}-0.0629 * * * \\
(-3.29)\end{array}$ \\
\hline children_dum & $\begin{array}{l}0.0508 \\
(1.10)\end{array}$ & $\begin{array}{l}0.0192 \\
(0.40)\end{array}$ & $\begin{array}{c}0.0592 \\
(1.28)\end{array}$ & $\begin{array}{l}0.0213 \\
(0.44)\end{array}$ \\
\hline house_ownership & $\begin{array}{c}0.267 * * * \\
(5.63)\end{array}$ & $\begin{array}{c}0.250 * * * \\
(5.21)\end{array}$ & $\begin{array}{c}0.242 * * * \\
(4.85)\end{array}$ & $\begin{array}{c}0.235 * * * \\
(4.65)\end{array}$ \\
\hline unemployment_dum & -0.0415 & 0.00639 & -0.0473 & 0.00778 \\
\hline insurance_literacy & $\begin{array}{c}(-0.63) \\
0.511 * * *\end{array}$ & $\begin{array}{c}(0.10) \\
0.459 * * *\end{array}$ & $\begin{array}{c}(-0.72) \\
0.526 * * *\end{array}$ & $\begin{array}{c}(0.12) \\
0.465^{* * *}\end{array}$ \\
\hline & (20.31) & $(17.55)$ & $(20.45)$ & (17.58) \\
\hline good_experience & & $\begin{array}{c}0.994 * * * \\
(21.21)\end{array}$ & & $\begin{array}{c}0.992 * * * \\
(20.83)\end{array}$ \\
\hline bad_experience & & $\begin{array}{c}-1.113 * * * \\
(-24.08)\end{array}$ & & $\begin{array}{c}-1.102 * * * \\
(-23.34)\end{array}$ \\
\hline optimism & & $\begin{array}{c}0.149 * * * \\
(2.66)\end{array}$ & & $\begin{array}{c}0.156 * * * \\
(2.79)\end{array}$ \\
\hline future_orientation & & $\begin{array}{c}-0.0911 * * * \\
(-3.95)\end{array}$ & & $\begin{array}{c}-0.0875 * * * \\
(-3.79)\end{array}$ \\
\hline altruism & & $\begin{array}{c}-0.0696 * * * \\
(-3.13)\end{array}$ & & $\begin{array}{c}-0.0751 * * * \\
(-3.37)\end{array}$ \\
\hline info_newspaper & & $\begin{array}{c}0.163 * \\
(1.94)\end{array}$ & & $\begin{array}{l}0.163 * \\
(1.94)\end{array}$ \\
\hline $\begin{array}{l}\text { info_internetsearchen } \\
\text { gine }\end{array}$ & & $-0.184 * * *$ & & $-0.195 * * *$ \\
\hline & & $(-4.12)$ & & $(-4.32)$ \\
\hline
\end{tabular}


U.K.

$0.416^{* * *} \quad 0.357^{* * * *}$

GERMANY

(4.41)

$-0.00502$

$-0.0846$

ITALY

$(-0.06)$

$0.221 * * *$

$0.139 *$

(2.70)

(1.68)

JAPAN

$0.395 * * *$

$0.209 * *$

SWITZERLAND

$0.421 * * *$

$0.329 * * *$

(5.06)

(3.89)

USA

$0.331 * * *$

$0.251 * * *$

\begin{tabular}{llllc} 
& & & $(4.05)$ & $(3.03)$ \\
\hline$N$ & 7384 & 7384 & 7384 & 7384 \\
$R^{2}$ & 0.0253 & 0.0708 & 0.0284 & 0.0732 \\
\hline
\end{tabular}

This table displays the main regression results of the ordered logit model. The dependent variable in all regressions is TRUST_INS_COMP; trust in insurance companies. Detailed definition of all variables is provided in Table A1, Appendix A. The country dummy for France is dropped for collinearity. Reported beneath each coefficient estimate in parenthesis is the $t$-statistic. *,** and ***indicate statistical significance at the $10 \%, 5 \%$ and $1 \%$ levels, respectively. $R^{2}$ reported is the pseudo $R$-squared. 
Table 5. Determinants of Trust in Insurance - Marginal Effects

\begin{tabular}{|c|c|c|c|c|c|}
\hline & Response (1) & Response (2) & Response (3) & Response (4) & Response (5) \\
\hline gender & $0.0183 * * *$ & $0.0236 * * *$ & $-0.0117 * * *$ & $-0.0253 * * *$ & $-0.00483 * * *$ \\
\hline age & $0.000639 * * *$ & $0.000820 * * *$ & $0.000409 * * *$ & $0.000882 * * *$ & $-0.000168 * * *$ \\
\hline education & $0.00281 *$ & $0.00360^{*}$ & $-0.00180^{*}$ & $-0.00387 *$ & $-0.000738 *$ \\
\hline income & 0.00076 & 0.000977 & -0.000487 & -0.00105 & -0.0002 \\
\hline chiefincome_earner_dum & 0.000941 & 0.00121 & -0.000603 & -0.0013 & -0.000248 \\
\hline area_living & $0.00560 * * *$ & $0.00719 * * *$ & $-0.00358 * * *$ & $-0.00773 * * *$ & $-0.00147 * * *$ \\
\hline children & -0.000941 & -0.00121 & 0.000603 & 0.0013 & 0.000248 \\
\hline house_ownership & $-0.0220 * * *$ & $-0.0282 * * *$ & $0.0141 * * *$ & $0.0304 * * *$ & $0.00578 * * *$ \\
\hline unemployment & -0.000968 & -0.00124 & 0.00062 & 0.00134 & 0.000255 \\
\hline good_experience & $-0.0900 * * *$ & $-0.116^{* * *}$ & $0.0577 * * *$ & $0.124 * * *$ & $0.0237 * * *$ \\
\hline bad_experience & $0.0985^{* * *}$ & $0.127 * * *$ & $-0.0631 * * *$ & $-0.136^{* * *}$ & $-0.0259 * * *$ \\
\hline insurance literacy & $-0.0428 * * *$ & $-0.0550 * * *$ & $0.0274 * * *$ & $0.0592 * * *$ & $0.0113 * * *$ \\
\hline Optimisim & $-0.0136 * * *$ & $-0.0175^{* * *}$ & $0.00873 * * *$ & $0.0188 * * *$ & $0.00359 * * *$ \\
\hline Future_orientation & $0.00797 * * *$ & $0.0102 * * *$ & $-0.00511 * * *$ & $-0.0110 * * *$ & $-0.00210 * * *$ \\
\hline info_newspaper & $-0.0145^{*}$ & $-0.0187 *$ & $0.00931 *$ & $0.0201 *$ & $0.00382 *$ \\
\hline info_internet & $0.0172 * * *$ & $0.0221 * * *$ & $-0.0110 * * *$ & $-0.0238 * * *$ & $-0.00453^{* * *}$ \\
\hline
\end{tabular}


Table 6. Determinants of Trust in Insurance - Elements of a bad experience

\begin{tabular}{|c|c|c|c|c|}
\hline & $\begin{array}{c}\text { (1) } \\
\text { TRUST_INS } \\
\text { COMP }\end{array}$ & $\begin{array}{c}\text { (2) } \\
\text { TRUST_INS_ } \\
\text { COMP }\end{array}$ & $\begin{array}{c}\text { (3) } \\
\text { TRUST_INS_ } \\
\text { COMP }\end{array}$ & $\begin{array}{c}\text { (4) } \\
\text { TRUST_INS_CO } \\
\text { MP }\end{array}$ \\
\hline Delayed_Payment & $\begin{array}{c}-0.321 * * * \\
(-5.08)\end{array}$ & $\begin{array}{c}-0.259 * * * \\
(-4.05)\end{array}$ & $\begin{array}{c}-0.353 * * * \\
(-5.42)\end{array}$ & $\begin{array}{c}-0.283 * * * \\
(-4.30)\end{array}$ \\
\hline Difficulto_Claim & $\begin{array}{c}-0.256 * * * \\
(-3.84)\end{array}$ & $\begin{array}{c}-0.192 * * * \\
(-2.84)\end{array}$ & $\begin{array}{c}-0.291 * * * \\
(-4.27)\end{array}$ & $\begin{array}{c}-0.229 * * * \\
(-3.31)\end{array}$ \\
\hline Denied_Claim & $\begin{array}{c}-0.359 * * * \\
(-5.83)\end{array}$ & $\begin{array}{c}-0.329 * * * \\
(-5.28)\end{array}$ & $\begin{array}{c}-0.379 * * * \\
(-6.07)\end{array}$ & $\begin{array}{c}-0.327 * * * \\
(-5.18)\end{array}$ \\
\hline Complicated_PP & $\begin{array}{c}-0.184^{*} \\
(-1.96)\end{array}$ & $\begin{array}{c}-0.189 * * \\
(-1.99)\end{array}$ & $\begin{array}{c}-0.256 * * * \\
(-2.70)\end{array}$ & $\begin{array}{c}-0.261 * * * \\
(-2.73)\end{array}$ \\
\hline Controls & YES & YES & YES & YES \\
\hline Country Dummies & $\mathrm{NO}$ & $\mathrm{NO}$ & YES & YES \\
\hline$N$ & 3933 & 3933 & 3933 & 3933 \\
\hline$R^{2}$ & 0.0358 & 0.0677 & 0.0417 & 0.0726 \\
\hline
\end{tabular}


Table 7. Determinants of Trust in Insurance - Country-Level Analysis

\begin{tabular}{|c|c|c|c|c|c|c|c|}
\hline & (1) & (2) & (3) & (4) & (5) & (6) & (7) \\
\hline & FRANCE & U.K. & GERMANY & ITALY & JAPAN & $\begin{array}{c}\text { SWITZER } \\
\text { LAND }\end{array}$ & USA \\
\hline \multirow{2}{*}{$\begin{array}{l}\text { good_experi } \\
\text { ence }\end{array}$} & $1.026 * * *$ & $1.001 * * *$ & $0.818 * * *$ & $1.040 * * *$ & $0.775^{* * *} *$ & $1.088 * * *$ & $1.238 * * *$ \\
\hline & (8.09) & (8.14) & $(6.52)$ & (8.09) & $(5.54)$ & $(8.46)$ & (9.91) \\
\hline \multirow{2}{*}{$\begin{array}{l}\text { bad_experie } \\
\text { nce }\end{array}$} & $-1.267 * * *$ & $-1.110 * * *$ & $-1.174 * * *$ & $-1.238 * * *$ & $-0.750 * * *$ & $-0.974 * * *$ & $-1.169 * * *$ \\
\hline & $(-10.04)$ & $(-9.22)$ & $(-9.45)$ & $(-9.63)$ & $(-5.24)$ & $(-7.70)$ & $(-9.53)$ \\
\hline \multirow{2}{*}{$\begin{array}{l}\text { insurance_lit } \\
\text { eracy }\end{array}$} & $0.506^{* * *} *$ & $0.611 * * *$ & $0.538 * * *$ & $0.627 * * *$ & $0.458 * * *$ & $0.186^{* * *} *$ & $0.350 * * *$ \\
\hline & (6.78) & (8.49) & $(7.36)$ & (8.19) & (6.98) & (2.59) & $(5.24)$ \\
\hline Controls & YES & YES & YES & YES & YES & YES & YES \\
\hline$N$ & 1041 & 1141 & 1013 & 1046 & 996 & 1017 & 1130 \\
\hline$R^{2}$ & 0.0786 & 0.0915 & 0.0892 & 0.0987 & 0.0533 & 0.0620 & 0.0822 \\
\hline
\end{tabular}


Table 8. Determinants of Trust in Insurance Reimbursment

\begin{tabular}{|c|c|c|c|c|}
\hline & $\begin{array}{l}\text { (1) } \\
\text { trust_insurance_ } \\
\text { reimb }\end{array}$ & $\begin{array}{l}(2) \\
\text { trust_insurance_ } \\
\text { reimb }\end{array}$ & $\begin{array}{l}\text { (3) } \\
\text { trust_insurance } \\
\text { reimb }\end{array}$ & $\begin{array}{c}\text { (4) } \\
\text { trust_insurance } \\
\text { reimb }\end{array}$ \\
\hline gender & $\begin{array}{c}-0.0966^{* * *} \\
(-2.07)\end{array}$ & $\begin{array}{c}-0.0817 * \\
(-1.74)\end{array}$ & $\begin{array}{c}-0.153 * * * \\
(-3.21)\end{array}$ & $\begin{array}{c}-0.133 * * * \\
(-2.77)\end{array}$ \\
\hline age & $\begin{array}{c}-0.00255^{*} \\
(-1.75)\end{array}$ & $\begin{array}{c}-0.00212 \\
(-1.45)\end{array}$ & $\begin{array}{c}-0.00452 * * * \\
(-3.07)\end{array}$ & $\begin{array}{c}-0.00415 * * * \\
(-2.79)\end{array}$ \\
\hline education & $\begin{array}{r}-0.0209 \\
(-1.34)\end{array}$ & $\begin{array}{c}-0.0223 \\
(-1.41)\end{array}$ & $\begin{array}{c}0.00139 \\
(0.09)\end{array}$ & $\begin{array}{c}0.00336 \\
(0.21)\end{array}$ \\
\hline income & $\begin{array}{l}0.0224 \\
(0.72)\end{array}$ & $\begin{array}{c}0.00465 \\
(0.15)\end{array}$ & $\begin{array}{c}0.0443 \\
(1.40)\end{array}$ & $\begin{array}{c}0.0253 \\
(0.79)\end{array}$ \\
\hline $\begin{array}{l}\text { chiefincome_earner } \\
\text { dum }\end{array}$ & -0.0501 & -0.0459 & 0.0353 & 0.0356 \\
\hline & $(-0.95)$ & $(-0.87)$ & $(0.66)$ & $(0.66)$ \\
\hline area_living & $\begin{array}{c}-0.0852 * * * \\
(-4.63)\end{array}$ & $\begin{array}{c}-0.0863 * * * \\
(-4.66)\end{array}$ & $\begin{array}{c}-0.0458^{* *} \\
(-2.39)\end{array}$ & $\begin{array}{c}-0.0450^{* *} \\
(-2.34)\end{array}$ \\
\hline children_dum & $\begin{array}{l}0.0586 \\
(1.26)\end{array}$ & $\begin{array}{c}-0.0184 \\
(-0.38)\end{array}$ & $\begin{array}{c}0.0853^{*} \\
(1.83)\end{array}$ & $\begin{array}{c}0.0195 \\
(0.40)\end{array}$ \\
\hline house_ownership & $\begin{array}{c}-0.00246 \\
(-0.05)\end{array}$ & $\begin{array}{c}-0.0136 \\
(-0.28)\end{array}$ & $\begin{array}{c}0.0917 * \\
(1.83)\end{array}$ & $\begin{array}{c}0.0783 \\
(1.55)\end{array}$ \\
\hline $\begin{array}{l}\text { unemployment_du } \\
\text { m }\end{array}$ & $-0.139 * *$ & -0.0926 & -0.0668 & -0.0207 \\
\hline insurance_literacy & $\begin{array}{c}(-2.11) \\
0.367 * * *\end{array}$ & $\begin{array}{c}(-1.40) \\
0.286^{* * *}\end{array}$ & $\begin{array}{c}(-1.01) \\
0.345^{* * *}\end{array}$ & $\begin{array}{c}(-0.31) \\
0.274 * * *\end{array}$ \\
\hline & $(14.82)$ & $(11.20)$ & (13.52) & $(10.52)$ \\
\hline good_experience & & $\begin{array}{c}0.819 * * * \\
(17.57)\end{array}$ & & $\begin{array}{c}0.792 * * * \\
(16.65)\end{array}$ \\
\hline bad_experience & & $\begin{array}{c}-0.576 * * * \\
(-12.76)\end{array}$ & & $\begin{array}{c}-0.594 * * * \\
(-12.79)\end{array}$ \\
\hline Optimism & & $\begin{array}{c}0.119 * * \\
(2.14)\end{array}$ & & $\begin{array}{l}0.0807 \\
(1.43)\end{array}$ \\
\hline Future_orientation & & $\begin{array}{c}-0.0920 * * * \\
(-3.97)\end{array}$ & & $\begin{array}{c}-0.112 * * * \\
(-4.81)\end{array}$ \\
\hline Altruism & & $\begin{array}{c}-0.105 * * * \\
(-4.72)\end{array}$ & & $\begin{array}{c}-0.0863 * * * \\
(-3.85)\end{array}$ \\
\hline info_newspaper & & $\begin{array}{c}0.210 * * \\
(2.52)\end{array}$ & & $\begin{array}{c}0.143^{*} \\
(1.70)\end{array}$ \\
\hline $\begin{array}{l}\text { info_internetsearch } \\
\text { engine }\end{array}$ & & 0.0130 & & -0.0271 \\
\hline & & $(0.29)$ & & $(-0.60)$ \\
\hline Country Dummies & NO & NO & YES & YES \\
\hline$N$ & 7384 & 7384 & 7384 & 7384 \\
\hline$R^{2}$ & 0.0139 & 0.0364 & 0.0384 & 0.0599 \\
\hline
\end{tabular}


Table 9. Disentangling the effect of education and insurance literacy on trust in insurance

\section{(1)}

\section{Education}

Some secondary

school

Finished secondary

school

Vocational school/

Technical college

Some university/

higher education

University degree,

Honors degree

Post-graduate

degree

$-0.500 * * *$
$(-2.70)$
$-0.372 * *$

$(-2.18)$

$-0.476^{* * *}$

$(-2.80)$

$-0.571 * * *$

$(-3.32)$

$-0.432 * *$

$(-2.50)$

$-0.586 * * *$

$(-3.18)$
(2)

$-0.516^{* * *}$
$(-2.75)$
$-0.346^{* *}$

$(-1.99)$

$-0.442 * *$

$(-2.56)$

$-0.533 * * *$

$(-3.05)$

$-0.408 * *$

$(-2.32)$

$-0.491 * * *$

$(-2.63)$
(3)

(4)

$-0.503 * * *$

$-0.354 * *$

$-0.406^{* *}$

$(-2.34)$

$(-2.01)$

$-0.436 * *$

$(-2.52)$

$(-2.84)$

$-0.640 * * *$

$-0.557 * * *$

$(-3.13)$

$(-3.65)$

$-0.443 * *$

$-0.410^{* *}$

$(-2.31)$

$(-2.54)$

$-0.606^{* * *}$

$-0.502 * * *$

$(-3.26)$

$(-2.66)$

\section{Insurance \\ Literacy \\ Poor}

$0.477 * * *$

(5.42)

Fair

$0.926 * * *$

$0.440^{* * *}$

(4.89)

$0.869 * * *$

(10.71)

Good

$1.432 * * *$

(9.78)

(14.79)

$1.257 * * *$

(12.59)

Very Good

$2.480 * * *$

$2.312 * * *$

Country FE

(15.02)

(13.75)

YES

YES

YES

YES

Controls

7384

7384

0.0269

0.0724

$0.505 * * *$

$0.452 * * *$

(5.70)

$0.975 * * *$

(5.01)

0.886 ***

(11.11)

$1.487 * * *$

(9.87)

(15.16)

$1.286 * * *$

(12.78)

$2.531 * * *$

$2.333 * * *$

(15.23)

(13.84)

YES

YES

YES

YES

7384

7384

$R^{2}$

This table displays the regression results of the ordered logit model using binary independent variables for education and insurance literacy.

All other variables in model 4 are included in the regression but not reported to gain space. The dependent variable in all regressions is

TRUST_INS_COMP; trust in insurance companies. Detailed definition of all variables is provided in Table A1, Appendix A. Reported

beneath each coefficient estimate in parenthesis is the $t$-statistic. *, ** and *** indicate statistical significance at the $10 \%, 5 \%$ and $1 \%$

levels, respectively. $R^{2}$ reported is the pseudo $R$-squared. 


\section{Appendix A}

Table A1. Variable Description

\begin{tabular}{|c|c|c|}
\hline Variable & Description & Details \\
\hline TRUST_INS_COMP & $\begin{array}{l}\text { Answer to the following question: } \\
\text { When thinking about insurance } \\
\text { companies, how much do you agree } \\
\text { or disagree with the following } \\
\text { statements: Insurance companies are } \\
\text { honest and trustworthy? }\end{array}$ & $\begin{array}{l}1 \text { strongly disagree, } 2 \text { somewhat } \\
\text { disagree, } 3 \text { neither agree nor } \\
\text { disagree, } 4 \text { somewhat agree, } 5 \\
\text { strongly agree }\end{array}$ \\
\hline gender & Male or Female & 1 for male, 0 for female \\
\hline age & age in number of years & $18-99$ \\
\hline education & Last grade in school completed & $\begin{array}{l}1 \text { graduate school or less, } 2 \text { some } \\
\text { secondary school or equivalent, } \\
3 \text { finishes secondary school or } \\
\text { equivalent, } 4 \text { vocational } \\
\text { school/technical school, } 5 \text { some } \\
\text { university/higher education, } 6 \\
\text { university degree/honors degree, } \\
7 \text { post-graduate degree }\end{array}$ \\
\hline income & $\begin{array}{l}\text { Interval of household annual income } \\
\text { in } 2017\end{array}$ & $\begin{array}{l}1 \text { for low income, } 2 \text { for middle } \\
\text { income, } 3 \text { for high income }\end{array}$ \\
\hline $\begin{array}{l}\text { chiefincome_earner_du } \\
\mathrm{m}\end{array}$ & $\begin{array}{l}\text { Dummy for being the chief income } \\
\text { earner in the household }\end{array}$ & $\begin{array}{l}1 \text { if the subject is the income } \\
\text { earner and } 0 \text { otherwise }\end{array}$ \\
\hline area_living & Living area characteristics & $\begin{array}{l}1 \text { for the heart of a large city, } 2 \\
\text { for an urban area, } 3 \text { for a } \\
\text { suburban area, } 4 \text { for a semi-rural } \\
\text { area, } 5 \text { for a rural area }\end{array}$ \\
\hline Children_dum & Having children & $\begin{array}{l}1 \text { for having } 1 \text { or more children } \\
\text { and } 0 \text { otherwise }\end{array}$ \\
\hline house_ownership & House ownership dummy & $\begin{array}{l}1 \text { if the house is owned and } 0 \\
\text { otherwise }\end{array}$ \\
\hline unemployment & Unemployment dummy & 1 if unemployed, 0 otherwise \\
\hline optimism & $\begin{array}{l}\text { Answer to the following question: } \\
\text { Do you consider yourself } \\
\text { optimistic? }\end{array}$ & 1 if yes, 0 otherwise \\
\hline future_orientation & $\begin{array}{l}\text { Answer to the following question: I } \\
\text { tend to focus on the present more } \\
\text { than the future }\end{array}$ & $\begin{array}{l}1 \text { strongly agree, } 2 \text { somewhat } \\
\text { agree, } 3 \text { neither agree nor } \\
\text { disagree, } 4 \text { somewhat disagree, } 5 \\
\text { strongly disagree }\end{array}$ \\
\hline altruism & $\begin{array}{l}\text { Answer to the following question: I } \\
\text { feel responsible for taking care of } \\
\text { my family }\end{array}$ & $\begin{array}{l}1 \text { strongly agree, } 2 \text { somewhat } \\
\text { agree, } 3 \text { neither agree nor } \\
\text { disagree, } 4 \text { somewhat disagree, } 5 \\
\text { strongly disagree }\end{array}$ \\
\hline good_experience & $\begin{array}{l}\text { Answer to the following question: } \\
\text { Have you ever had, or know } \\
\text { someone who has had, a good } \\
\text { experience with insurance? }\end{array}$ & 1 if yes, 0 otherwise \\
\hline bad_experience & $\begin{array}{l}\text { Answer to the following question: } \\
\text { Have you ever had, or know } \\
\text { someone who has had, a bad } \\
\text { experience with insurance? }\end{array}$ & 1 if yes, 0 otherwise \\
\hline
\end{tabular}




\begin{tabular}{|l|l|l|}
\hline insurance_literacy & $\begin{array}{l}\text { Answer to the following question: } \\
\text { How would you qualify your level } \\
\text { of understanding/knowledge of the } \\
\text { following industries? }\end{array}$ & $\begin{array}{l}1 \text { very poor, 2 poor, } 3 \text { fair, } 4 \\
\text { good, 5 very good }\end{array}$ \\
\hline info_newspaper & $\begin{array}{l}\text { Answer to the following question: } \\
\text { Do you search for information } \\
\text { regarding insurance products using } \\
\text { newspapers/magazines? }\end{array}$ & 1 if yes, 0 otherwise \\
\hline info_internet & $\begin{array}{l}\text { Answer to the following question: } \\
\text { Do you search for information } \\
\text { regarding insurance products using } \\
\text { an internet search engine? }\end{array}$ & 1 if yes, 0 otherwise \\
\hline
\end{tabular}




\section{Appendix B}

Table B1. Robustness Check - OLS

\begin{tabular}{|c|c|c|c|c|}
\hline & $(1)$ & (2) & (3) & (4) \\
\hline gender & $\begin{array}{c}-0.0939 * * * \\
(-3.95)\end{array}$ & $\begin{array}{c}-0.0796 * * * \\
(-3.55)\end{array}$ & $\begin{array}{c}-0.106^{* * *} \\
(-4.40)\end{array}$ & $\begin{array}{c}-0.0829 * * * \\
(-3.65)\end{array}$ \\
\hline age & $\begin{array}{c}-0.00336 * * * \\
(-4.54)\end{array}$ & $\begin{array}{c}-0.00371 * * * \\
(-5.32)\end{array}$ & $\begin{array}{c}-0.00338 * * * \\
(-4.56)\end{array}$ & $\begin{array}{c}-0.00364 * * * \\
\quad(-5.20)\end{array}$ \\
\hline education & $\begin{array}{c}-0.0196^{* *} \\
(-2.46)\end{array}$ & $\begin{array}{c}-0.0134^{*} \\
(-1.77)\end{array}$ & $\begin{array}{c}-0.0214 * * * \\
(-2.65)\end{array}$ & $\begin{array}{c}-0.0152^{* *} \\
(-2.00)\end{array}$ \\
\hline income & $\begin{array}{c}-0.00950 \\
(-0.60)\end{array}$ & $\begin{array}{c}-0.0192 \\
(-1.28)\end{array}$ & $\begin{array}{c}-0.000662 \\
(-0.04)\end{array}$ & $\begin{array}{c}-0.0134 \\
(-0.88)\end{array}$ \\
\hline $\begin{array}{l}\text { chiefincome_earner } \\
\text { _dum }\end{array}$ & -0.0250 & -0.0145 & -0.00869 & -0.00483 \\
\hline & $(-0.93)$ & $(-0.58)$ & $(-0.32)$ & $(-0.19)$ \\
\hline area_living & $\begin{array}{c}-0.0307 * * * \\
(-3.31)\end{array}$ & $\begin{array}{l}-0.0257 * * * \\
(-2.95)\end{array}$ & $\begin{array}{c}-0.0338 * * * \\
(-3.53)\end{array}$ & $\begin{array}{c}-0.0316^{* * *} \\
(-3.50)\end{array}$ \\
\hline children_dum & $\begin{array}{l}0.0328 \\
(1.39)\end{array}$ & $\begin{array}{c}0.0122 \\
(0.53)\end{array}$ & $\begin{array}{c}0.0358 \\
(1.52)\end{array}$ & $\begin{array}{c}0.0121 \\
(0.53)\end{array}$ \\
\hline house_ownership & $\begin{array}{l}0.141 * * * \\
\quad(5.86)\end{array}$ & $\begin{array}{l}0.123 * * * \\
\quad(5.43)\end{array}$ & $\begin{array}{l}0.131 * * * \\
\quad(5.15)\end{array}$ & $\begin{array}{c}0.117 * * * \\
(4.88)\end{array}$ \\
\hline $\begin{array}{l}\text { unemployment_du } \\
\mathrm{m}\end{array}$ & -0.0203 & -0.0000374 & -0.0246 & 0.000125 \\
\hline & $(-0.61)$ & $(-0.00)$ & $(-0.73)$ & $(0.00)$ \\
\hline insurance_literacy & $\begin{array}{c}0.252 * * * \\
(20.73)\end{array}$ & $\begin{array}{c}0.210 * * * \\
(17.71)\end{array}$ & $\begin{array}{c}0.257 * * * \\
(20.75)\end{array}$ & $\begin{array}{c}0.211 * * * \\
(17.66)\end{array}$ \\
\hline good_experience & & $\begin{array}{c}0.480 * * * \\
(22.11)\end{array}$ & & $\begin{array}{c}0.479 * * * \\
(21.76)\end{array}$ \\
\hline bad_experience & & $\begin{array}{c}-0.521 * * * \\
(-24.55)\end{array}$ & & $\begin{array}{c}-0.514 * * * \\
(-23.78)\end{array}$ \\
\hline optimism & & $\begin{array}{l}0.0686^{* * * *} \\
(2.59)\end{array}$ & & $\begin{array}{l}0.0716^{* * * *} \\
\quad(2.70)\end{array}$ \\
\hline future_orientation & & $\begin{array}{c}-0.0413 * * * \\
(-3.87)\end{array}$ & & $\begin{array}{c}-0.0397 * * * \\
\quad(-3.71)\end{array}$ \\
\hline altruism & & $\begin{array}{c}-0.0319 * * * \\
(-3.05)\end{array}$ & & $\begin{array}{c}-0.0350 * * * \\
(-3.34)\end{array}$ \\
\hline info_newspaper & & $\begin{array}{c}0.0722 * \\
(1.83)\end{array}$ & & $\begin{array}{c}0.0727 * \\
(1.85)\end{array}$ \\
\hline $\begin{array}{l}\text { info_internetsearche } \\
\text { ngine }\end{array}$ & & $\begin{array}{c}-0.0884 * * * \\
(-4.16)\end{array}$ & & $\begin{array}{c}-0.0933 * * * \\
(-4.36)\end{array}$ \\
\hline U.K. & & & $\begin{array}{l}0.181 * * * \\
(4.49)\end{array}$ & $\begin{array}{c}0.155^{* * * *} \\
(4.06)\end{array}$ \\
\hline GERMANY & & & $\begin{array}{l}-0.0152 \\
(-0.36)\end{array}$ & $\begin{array}{l}-0.0433 \\
(-1.10)\end{array}$ \\
\hline ITALY & & & $\begin{array}{l}0.0829 * * \\
(1.98)\end{array}$ & $\begin{array}{l}0.0461 \\
(1.17)\end{array}$ \\
\hline JAPAN & & & $\begin{array}{l}0.181 * * * \\
\quad(4.19)\end{array}$ & $\begin{array}{l}0.0903 * * \\
(2.20)\end{array}$ \\
\hline SWITZERLAND & & & $\begin{array}{c}0.191 * * * \\
(4.55)\end{array}$ & $\begin{array}{c}0.140 * * * \\
(3.53)\end{array}$ \\
\hline USA & & & $\begin{array}{c}0.147 * * * \\
(3.59)\end{array}$ & $\begin{array}{l}0.107 * * * \\
(2.76)\end{array}$ \\
\hline Constant & $2.346 * * *$ & $2.686 * * *$ & $2.222 * * *$ & 2.619 *** \\
\hline
\end{tabular}




\begin{tabular}{lcccc}
\hline$N$ & 7384 & 7384 & 7384 & 7384 \\
$R^{2}$ & 0.068 & 0.177 & 0.075 & 0.182 \\
\hline
\end{tabular}

This table displays the main regression results using ordinary least (OLS). The dependent variable in all regressions is TRUST_INS_COMP; trust in insurance companies. Detailed definition of all variables is provided in Table A1, Appendix A. The country dummy for France is dropped for collinearity. Reported beneath each coefficient estimate in parenthesis is the t-statistic. *,**and *** indicate statistical significance at the $10 \%, 5 \%$ and $1 \%$ levels, respectively. $R^{2}$ reported is the pseudo $R$-squared. 
Table B2. Robustness Check - Binary Dependent Variable, Logit Model

\begin{tabular}{|c|c|c|c|c|}
\hline & $(1)$ & (2) & (3) & (4) \\
\hline gender & $\begin{array}{c}-0.203 * * * \\
(-2.78)\end{array}$ & $\begin{array}{c}-0.159 * * \\
(-1.99)\end{array}$ & $\begin{array}{c}-0.224 * * * \\
(-3.00)\end{array}$ & $\begin{array}{c}-0.162 * * \\
(-1.99)\end{array}$ \\
\hline age & $\begin{array}{c}-0.00985^{* * * *} \\
(-4.41)\end{array}$ & $\begin{array}{c}-0.0124 * * * \\
(-5.09)\end{array}$ & $\begin{array}{c}-0.0101 * * * \\
(-4.47)\end{array}$ & $\begin{array}{c}-0.0125 * * * \\
(-5.11)\end{array}$ \\
\hline education & $\begin{array}{c}-0.0275 \\
(-1.14)\end{array}$ & $\begin{array}{c}-0.0144 \\
(-0.55)\end{array}$ & $\begin{array}{c}-0.0315 \\
(-1.28)\end{array}$ & $\begin{array}{c}-0.0198 \\
(-0.74)\end{array}$ \\
\hline income & $\begin{array}{c}-0.0348 \\
(-0.72)\end{array}$ & $\begin{array}{c}-0.0871 * \\
(-1.65)\end{array}$ & $\begin{array}{l}-0.0179 \\
(-0.36)\end{array}$ & $\begin{array}{l}-0.0755 \\
(-1.41)\end{array}$ \\
\hline $\begin{array}{l}\text { chiefincome_earner } \\
\text { _dum }\end{array}$ & -0.0790 & -0.0508 & -0.0518 & -0.0319 \\
\hline & $(-0.96)$ & $(-0.57)$ & $(-0.62)$ & $(-0.35)$ \\
\hline area_living & $\begin{array}{c}-0.0483^{*} \\
(-1.73)\end{array}$ & $\begin{array}{c}-0.0539 * \\
(-1.77)\end{array}$ & $\begin{array}{c}-0.0694 * * \\
(-2.38)\end{array}$ & $\begin{array}{c}-0.0813 * * \\
(-2.55)\end{array}$ \\
\hline children_dum & $\begin{array}{l}0.0922 \\
(1.28)\end{array}$ & $\begin{array}{l}0.0272 \\
(0.33)\end{array}$ & $\begin{array}{l}0.104 \\
(1.43)\end{array}$ & $\begin{array}{c}0.0317 \\
(0.39)\end{array}$ \\
\hline house_ownership & $\begin{array}{c}0.323 * * * \\
(4.39)\end{array}$ & $\begin{array}{c}0.309 * * * \\
(3.86)\end{array}$ & $\begin{array}{c}0.348 * * * \\
(4.43)\end{array}$ & $\begin{array}{c}0.331 * * * \\
(3.87)\end{array}$ \\
\hline $\begin{array}{l}\text { unemployment_du } \\
\mathrm{m}\end{array}$ & -0.0771 & -0.0570 & -0.0885 & -0.0627 \\
\hline & $(-0.73)$ & $(-0.50)$ & $(-0.83)$ & $(-0.54)$ \\
\hline insurance_literacy & $\begin{array}{c}0.716^{* * * *} \\
(18.65)\end{array}$ & $\begin{array}{c}0.671 * * * \\
(15.90)\end{array}$ & $\begin{array}{c}0.716 * * * \\
(18.24)\end{array}$ & $\begin{array}{c}0.669 * * * \\
(15.63)\end{array}$ \\
\hline good_experience & & $\begin{array}{c}1.420 * * * \\
(17.80)\end{array}$ & & $\begin{array}{c}1.414 * * * \\
(17.38)\end{array}$ \\
\hline bad_experience & & $\begin{array}{c}-1.499 * * * \\
(-18.88)\end{array}$ & & $\begin{array}{c}-1.502 * * * \\
(-18.57)\end{array}$ \\
\hline optimism & & $\begin{array}{c}0.283^{* * * *} \\
(3.09)\end{array}$ & & $\begin{array}{c}0.300 * * * \\
(3.23)\end{array}$ \\
\hline future_orientation & & $\begin{array}{c}-0.141 * * * \\
(-3.88)\end{array}$ & & $\begin{array}{c}-0.140 * * * \\
(-3.81)\end{array}$ \\
\hline altruism & & $\begin{array}{c}-0.116^{* * *} \\
(-3.07)\end{array}$ & & $\begin{array}{c}-0.126 * * * \\
(-3.31)\end{array}$ \\
\hline info_newspaper & & $\begin{array}{l}0.247^{*} \\
(1.88)\end{array}$ & & $\begin{array}{c}0.260 * * \\
(1.97)\end{array}$ \\
\hline $\begin{array}{l}\text { info_internetsearche } \\
\text { ngine }\end{array}$ & & $\begin{array}{c}-0.320 * * * \\
(-4.23)\end{array}$ & & $\begin{array}{c}-0.338^{* * * *} \\
(-4.40)\end{array}$ \\
\hline U.K. & & & $\begin{array}{c}0.417 * * * \\
(3.43)\end{array}$ & $\begin{array}{c}0.430 * * * \\
(3.22)\end{array}$ \\
\hline GERMANY & & & $\begin{array}{c}0.0306 \\
(0.24)\end{array}$ & $\begin{array}{c}-0.0479 \\
(-0.35)\end{array}$ \\
\hline ITALY & & & $\begin{array}{c}0.0535 \\
(0.40)\end{array}$ & $\begin{array}{c}-0.0641 \\
(-0.44)\end{array}$ \\
\hline JAPAN & & & $\begin{array}{c}0.350 * * \\
(2.57)\end{array}$ & $\begin{array}{l}0.195 \\
(1.32)\end{array}$ \\
\hline SWITZERLAND & & & $\begin{array}{c}0.538 * * * \\
(4.34)\end{array}$ & $\begin{array}{c}0.423 * * * \\
(3.12)\end{array}$ \\
\hline USA & & & $\begin{array}{c}0.382 * * * \\
(3.14)\end{array}$ & $\begin{array}{c}0.352 * * * \\
(2.63)\end{array}$ \\
\hline Constant & $\begin{array}{c}-2.000 * * * \\
(-9.26) \\
\end{array}$ & $\begin{array}{c}-1.017 * * * \\
(-3.75)\end{array}$ & $\begin{array}{c}-2.234 * * * \\
(-9.46) \\
\end{array}$ & $\begin{array}{c}-1.127 * * * \\
(-3.89) \\
\end{array}$ \\
\hline
\end{tabular}




\begin{tabular}{lcccc}
\hline$N$ & 4518 & 4518 & 4518 & 4518 \\
Pseudo $R^{2}$ & 0.0820 & 0.2029 & 0.0884 & 0.2083 \\
\hline
\end{tabular}

This table displays regression results using a logistic model. The dependent variable in all regressions is the binary variable dum_TRUST_INS_COMP; trust in insurance companies, which takes the values of one for high levels of trust in insurance and zero for low levels of trust in insurance. Detailed definition of all variables is provided in Table A1, Appendix A. The country dummy for France is dropped for collinearity. Reported beneath each coefficient estimate in parenthesis is the $t$-statistic. *, ** and *** indicate statistical significance at the $10 \%, 5 \%$ and $1 \%$ levels, respectively. $R^{2}$ reported is the pseudo $R$-squared. 
Table B3. Robustness Check - Excluding one country per regression

\begin{tabular}{|c|c|c|c|c|c|c|c|}
\hline & (1) & (2) & (3) & (4) & (5) & (6) & (7) \\
\hline excluded country & France & U.K. & Germany & Italy & Japan & Switzerland & USA \\
\hline gender & $\begin{array}{c}-0.205 * * * \\
(-3.93)\end{array}$ & $\begin{array}{c}-0.215 * * * \\
(-4.09)\end{array}$ & $\begin{array}{c}-0.155 * * * \\
(-3.00)\end{array}$ & $\begin{array}{c}-0.189 * * * \\
(-3.66)\end{array}$ & $\begin{array}{c}-0.187 * * * \\
(-3.70)\end{array}$ & $\begin{array}{c}-0.202 * * * \\
(-3.89)\end{array}$ & $\begin{array}{c}-0.230 * * * \\
(-4.39)\end{array}$ \\
\hline age & $\begin{array}{c}-0.00742 * * * \\
(-4.59)\end{array}$ & $\begin{array}{c}-0.00609 * * * \\
(-3.76)\end{array}$ & $\begin{array}{c}-0.00622 * * * \\
(-3.86)\end{array}$ & $\begin{array}{c}-0.00704 * * * \\
(-4.42)\end{array}$ & $\begin{array}{c}-0.00710 * * * \\
(-4.54)\end{array}$ & $\begin{array}{c}-0.00850 * * * \\
(-5.32)\end{array}$ & $\begin{array}{c}-0.00782 * * * \\
(-4.71)\end{array}$ \\
\hline education & $\begin{array}{c}-0.0439 * * \\
(-2.48)\end{array}$ & $\begin{array}{c}-0.0403 * * \\
(-2.29)\end{array}$ & $\begin{array}{c}-0.0305^{*} \\
(-1.77)\end{array}$ & $\begin{array}{c}-0.0203 \\
(-1.15)\end{array}$ & $\begin{array}{c}-0.0336 * * \\
(-1.99)\end{array}$ & $\begin{array}{c}-0.0179 \\
(-1.03)\end{array}$ & $\begin{array}{c}-0.0278 \\
(-1.59)\end{array}$ \\
\hline income & $\begin{array}{c}-0.00749 \\
(-0.22)\end{array}$ & $\begin{array}{c}-0.0222 \\
(-0.64)\end{array}$ & $\begin{array}{l}-0.0248 \\
(-0.72)\end{array}$ & $\begin{array}{c}-0.0282 \\
(-0.84)\end{array}$ & $\begin{array}{c}-0.00930 \\
(-0.26)\end{array}$ & $\begin{array}{c}-0.0469 \\
(-1.35)\end{array}$ & $\begin{array}{c}-0.0189 \\
(-0.54)\end{array}$ \\
\hline $\begin{array}{l}\text { chiefincome_ear } \\
\text { ner dum }\end{array}$ & 0.0224 & -0.0568 & -0.0415 & 0.00954 & 0.0293 & -0.00989 & -0.0137 \\
\hline & $(0.39)$ & $(-0.96)$ & $(-0.72)$ & $(0.16)$ & $(0.52)$ & $(-0.17)$ & $(-0.23)$ \\
\hline area_living & $\begin{array}{c}-0.0672 * * * \\
(-3.12)\end{array}$ & $\begin{array}{c}-0.0494 * * \\
(-2.42)\end{array}$ & $\begin{array}{c}-0.0818 * * * \\
(-3.93)\end{array}$ & $\begin{array}{c}-0.0709 * * * \\
(-3.46)\end{array}$ & $\begin{array}{c}-0.0622 * * * \\
(-3.13)\end{array}$ & $\begin{array}{c}-0.0602 * * * \\
(-2.88)\end{array}$ & $\begin{array}{c}-0.0507 * * \\
(-2.46)\end{array}$ \\
\hline children_dum & $\begin{array}{c}0.0348 \\
(0.66)\end{array}$ & $\begin{array}{c}0.00981 \\
(0.19)\end{array}$ & $\begin{array}{r}0.0221 \\
(0.42)\end{array}$ & $\begin{array}{c}-0.00803 \\
(-0.16)\end{array}$ & $\begin{array}{c}0.0288 \\
(0.56)\end{array}$ & $\begin{array}{c}0.0463 \\
(0.89)\end{array}$ & $\begin{array}{c}0.0216 \\
(0.41)\end{array}$ \\
\hline house_ownershi & $0.247 * * *$ & $0.221 * * *$ & $0.208 * * *$ & $0.262 * * *$ & $0.258 * * *$ & $0.222 * * *$ & $0.228 * * *$ \\
\hline $\mathrm{p}$ & $(4.47)$ & $(4.00)$ & $(3.80)$ & $(4.84)$ & $(4.75)$ & $(4.07)$ & $(4.18)$ \\
\hline $\begin{array}{l}\text { unemployment_- } \\
\text { dum }\end{array}$ & $\begin{array}{c}0.0699 \\
(0.97)\end{array}$ & $\begin{array}{r}-0.0125 \\
(-0.17)\end{array}$ & $\begin{array}{r}-0.0701 \\
(-0.99)\end{array}$ & $\begin{array}{r}-0.0245 \\
(-0.34)\end{array}$ & $\begin{array}{c}0.0360 \\
(0.49)\end{array}$ & $\begin{array}{c}0.0169 \\
(0.23)\end{array}$ & $\begin{array}{c}0.0402 \\
(0.54)\end{array}$ \\
\hline insurance_literac & $0.462 * * *$ & $0.439 * * *$ & $0.454 * * *$ & $0.447 * * *$ & $0.465 * * *$ & $0.507 * * *$ & $0.482 * * *$ \\
\hline $\mathrm{y}$ & $(16.28)$ & $(15.39)$ & (15.94) & $(15.80)$ & $(16.01)$ & $(17.76)$ & $(16.70)$ \\
\hline good_experience & $\begin{array}{c}0.996 * * * \\
(19.32)\end{array}$ & $\begin{array}{c}0.999 * * * \\
(19.26)\end{array}$ & $\begin{array}{c}1.022 * * * \\
(19.82)\end{array}$ & $\begin{array}{c}0.988 * * * \\
(19.19)\end{array}$ & $\begin{array}{l}1.023 * * * \\
(20.17)\end{array}$ & $\begin{array}{c}0.968 * * * \\
(18.85)\end{array}$ & $\begin{array}{c}0.947 * * * \\
(18.39)\end{array}$ \\
\hline bad_experience & $\begin{array}{c}-1.071 * * * \\
(-20.99)\end{array}$ & $\begin{array}{l}-1.110 * * * \\
(-21.59)\end{array}$ & $\begin{array}{c}-1.092 * * * \\
(-21.36)\end{array}$ & $\begin{array}{c}-1.085 * * * \\
(-21.26)\end{array}$ & $\begin{array}{c}-1.143 * * * \\
(-22.79)\end{array}$ & $\begin{array}{c}-1.120 * * * \\
(-21.98)\end{array}$ & $\begin{array}{c}-1.090 * * * \\
(-21.27)\end{array}$ \\
\hline optimism & $\begin{array}{c}0.162 * * * \\
(2.68)\end{array}$ & $\begin{array}{c}0.111 * \\
(1.85)\end{array}$ & $\begin{array}{c}0.171 * * * \\
(2.82)\end{array}$ & $\begin{array}{c}0.146^{* *} \\
(2.40)\end{array}$ & $\begin{array}{c}0.190 * * * \\
(3.12)\end{array}$ & $\begin{array}{c}0.170 * * * \\
(2.78)\end{array}$ & $\begin{array}{c}0.146 * * \\
(2.43)\end{array}$ \\
\hline
\end{tabular}




\begin{tabular}{|c|c|c|c|c|c|c|c|}
\hline future_ortientati & $-0.0787 * * *$ & $-0.0793 * * *$ & $-0.0873 * * *$ & $-0.0817 * * *$ & $-0.0932 * * *$ & $-0.111 * * *$ & $-0.0814 * * *$ \\
\hline & $(-3.10)$ & $(-3.16)$ & $(-3.50)$ & $(-3.32)$ & $(-3.83)$ & $(-4.41)$ & $(-3.22)$ \\
\hline altruism & $\begin{array}{c}-0.0885 * * * \\
(-3.68)\end{array}$ & $\begin{array}{c}-0.0816 * * * \\
(-3.33)\end{array}$ & $\begin{array}{c}-0.0583 * * \\
(-2.45)\end{array}$ & $\begin{array}{c}-0.0870 * * * \\
(-3.69)\end{array}$ & $\begin{array}{c}-0.0751 * * * \\
(-3.12)\end{array}$ & $\begin{array}{c}-0.0635 * * * \\
(-2.64)\end{array}$ & $\begin{array}{c}-0.0709 * * * \\
(-2.85)\end{array}$ \\
\hline info_newspaper & $\begin{array}{c}0.185^{* *} \\
(2.05)\end{array}$ & $\begin{array}{l}0.121 \\
(1.30)\end{array}$ & $\begin{array}{l}0.180 * \\
(1.94)\end{array}$ & $\begin{array}{l}0.142 \\
(1.61)\end{array}$ & $\begin{array}{c}0.185^{* *} * \\
(2.01)\end{array}$ & $\begin{array}{c}0.186 * * \\
(2.04)\end{array}$ & $\begin{array}{l}0.143 \\
(1.61)\end{array}$ \\
\hline $\begin{array}{l}\text { info_internetsear } \\
\text { chengine }\end{array}$ & $\begin{array}{c}-0.204 * * * \\
(-4.20)\end{array}$ & $\begin{array}{c}-0.149 * * * \\
(-3.00)\end{array}$ & $\begin{array}{c}-0.199 * * * \\
(-4.05)\end{array}$ & $-0.199 * * *$ & $\begin{array}{c}-0.234 * * * \\
(-4.82)\end{array}$ & $\begin{array}{c}-0.206 * * * \\
(-4.25)\end{array}$ & $-0.174 * * *$ \\
\hline $\begin{array}{l}\text { Country } \\
\text { Dummies }\end{array}$ & YES & YES & YES & YES & YES & YES & YES \\
\hline$N$ & 6343 & 6243 & 6371 & 6338 & 6388 & 6367 & 6254 \\
\hline PseudoR $^{2}$ & 0.0727 & 0.0715 & 0.0717 & 0.0709 & 0.0773 & 0.0769 & 0.0725 \\
\hline
\end{tabular}

This table displays the regression results of the ordered logit model with an exclusion of a country per regression analysis. The dependent variable in all regressions is TRUST INS COMP; trust in insurance

companies. Detailed definition of all variables is provided in Table A1, Appendix A. The country dummy for France is dropped for collinearity. Reported beneath each coefficient estimate in parenthesis is the t-statistic.

companies. Detailed definition of all variables is provided in Table Al, Appendix A. The country dummy for France is dropped ${ }^{*} * *$ indicate statistical significance at the $10 \%, 5 \%$ and $1 \%$ levels, respectively. $R^{2}$ reported is the pseudo $R$-squared. 